\title{
NOTE
}

\section{Red tides during spring 1998 in Hong Kong: is El Niño responsible?}

\author{
Kedong Yin ${ }^{1,2, *}$, Paul J. Harrison ${ }^{3}$, Jay Chen ${ }^{2}$, Wei Huang ${ }^{2}$, Pei-Yuan Qian ${ }^{1,2}$ \\ ${ }^{1}$ Department of Biology and ${ }^{2}$ The Centre for Coastal and Atmospheric Research, Hong Kong University of Science and Technology, \\ Clear Water Bay, Kowloon, Hong Kong SAR
}

${ }^{3}$ Oceanography, Department of Earth and Ocean Sciences, University of British Columbia, Vancouver, British Columbia V6T 1Z4, Canada

ABSTRACT: The magnitude of El Niño in 1997-98 was one of the strongest of the century. A series of red tides occurred in Hong Kong territorial waters between mid-March and midApril 1998, resulting in the loss of $\mathrm{HK} \$ 250$ (US\$32) million in fish kill damage. The causative species was Gyrodinium aureolum. We used a time series of satellite images to track the development of the harmful algal bloom and relate its movement to physical oceanographic conditions. Prior to the red tide event in Hong Kong, harmful algal blooms had occurred earlier (November 1997-February 1998) along the south China coast to the east of Hong Kong, although the species were different. The progression of harmful algal blooms from northeast to southwest coincided with the southwesterly movement of the south China Coastal Current as indicated by the satellite images of SST (sea surface temperature) from the satellite AVHRR. Remote sensing images of chlorophyll a (chl a) from SeaWiFS (sea-viewing wide field of view sensor) confirmed high near-shore chl a for the same region. The entire event coincided with the dramatic change in the oceanographic conditions of the northern portion of the South China Sea between 1997 and 1998 for the period of March to mid-April, as revealed in the weekly composite SST The SST images showed a warm tongue pointing north to the south China coast in 1998 versus a cold tongue pointing south in 1997 in the middle of the South China Sea. The differences are believed to be due to El Niño and responsible for setting up the physical oceanographic conditions which were favorable for the formation of harmful algal blooms along the south China coast. The warm tongue in SST suggested that the warm water from the South China Sea might have been piling up towards the south China coast. On the other hand, downwelling of the south China Coastal Current along the coast due to the Northeast Monsoon during March might have been moving against the South China Sea warm water at the bottom. As a result, the coastal waters of the south China coast including Hong Kong became trapped along the coast. Given local eutrophied conditions of the China coast, the outbreak of harmful algal blooms occurred over a coast-wide scale $(-400 \mathrm{~km})$ in winter 1997 and spring 1998 . It appears that the use of satellite SST images is helpful in detecting large-scale changes in oceanographic conditions and relating the changes to possible outbreak of harmful algal blooms

KEY WORDS: Red tides - E1 Niño $\cdot$ South China Sea Satellite images - SeaWiFS
A series of red tides occurred in Hong Kong territorial waters between mid-March and mid-April 1998, resulting in the loss of HK\$250 (US\$32) million in fish kill damage. Prior to the red tide event in Hong Kong, harmful algal blooms had occurred earlier along the south China coast to the east of Hong Kong. El Niño has been blamed for these red tides in 1998 (Holden 1998). The question is how? It is known that the magnitude of El Niño in 1997-98 was one of the strongest of the century (Kerr 1998) and was only matched by that in 1982-83. However, little is known about how El Niño affects the western Pacific Ocean, let alone the South China Sea.

It is common that harmful algal blooms occur several times in March and April every year in Hong Kong, but they are usually localized (Agriculture and Fisheries Dept data, Hong Kong Government, unpubl. list of red tides). However, during the red tide event in spring 1998 the fish kills were the most massive. The scale was the largest and the persistent period was the longest in the history of red tides in Hong Kong. A special pattern of red tide occurrences in 1998 was the progression of red tides from the northeast waters to the southern territorial waters of Hong Kong (Fig. 1). Fish kills were first reported on March 19 in Region A, then in Region B (Sham Wan) on March 27, and later spread to the south of Hong Kong Island (Region D) on April 9 and the south of Lantau Island (Region E) by May 2 (Fig. 1). The causative species identified was Gyrodinium aureolum (AFD unpubl.), which has often been reported as Gymnodinium mikimotoi in Japan, since the 2 species cannot be separated under a regular light microscope. Cell concentrations were high

•E-mail: kyin@ust.hk 


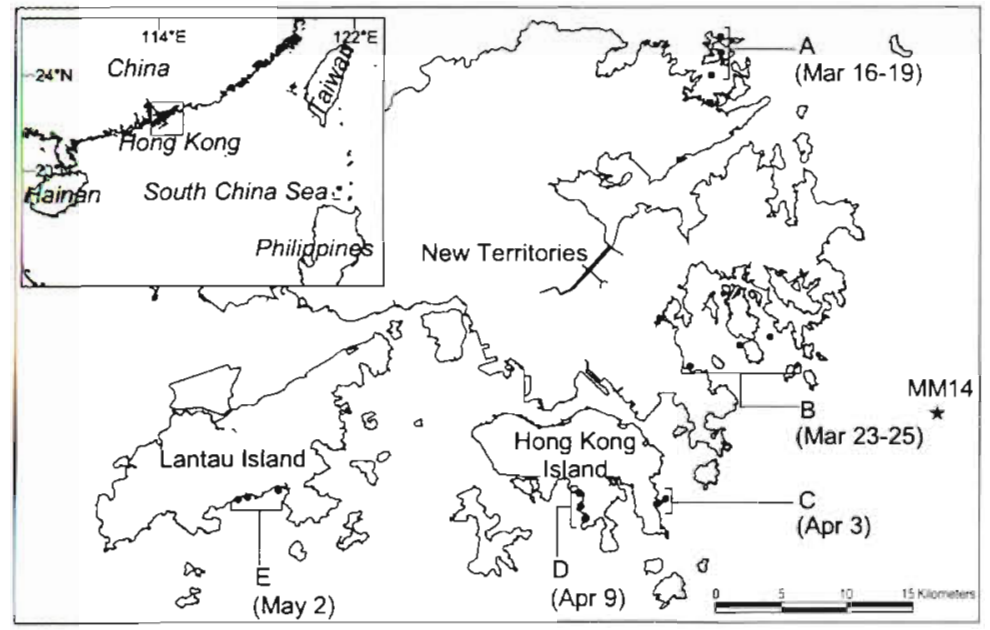

Fig. 1. The northeast-southwest development of red tides indicated by fish kills at selected sites in Hong Kong between March 19 and May 2, 1998

Fig. 2. Satellite images of chl a from SeaWiFS on November 4, 1997, and February 7 and April 4 to 10,1998 . The April 4 to 10 image is a composite of $7 \quad$ April 4,9 and 10,1998

and could reach 1 million cells $\mathrm{I}^{-1}$ in Junk Bay to the north of region $C$ (Fig. 1, Lu pers, comm.). In fact, from November 1997 until February 5, 1998, prior to the Hong Kong outbreak, red tides were reported to occur and persist in a large area along the Fuji coast and the Guangdong east coast (a newspaper report). The bloom species was Phaeocystis cf. Globosa (Qi pers. comm.). The satellite images from SeaWiFS clearly showed high near-shore chlorophyll a (chl a) concentrations in bands along the coast in November 1997 and February 1998 (Fig. 2). In mid-March, red tides occurred in neighboring waters to the east (Hui-Dong) of Hong Kong. After the Hong Kong event, red tides spread west to the Gui-Shan Island area near Zhuhai (north of Macau) (Qi pers. comm.). The causative species were identified as $G$. mikimotoi, Gyrodinium instritinum, Cochlodinium spp. and Alexandrium sp. (Qi pers. comm.). The extent of red tides was so large that they caused a financial loss of $\sim$ REM $\$ 400$ ( - US\$47) million in mainland China (Qi pers. comm.). Remote sensing images of chl a from SeaWiFS (sea-viewing wide field of view sensor) during April 5 to 10 showed that high near-shore chl a moved near Hong Kong and west of it (Fig. 2). Apparently, there was a progression of the red tides, suggesting that they were likely transported from the southeast coast of mainland China to the Hong Kong region. The spreading of harmful algal blooms from northeast to southwest along the south China coast between fall 1997 and February 1998 coincided with the movement of cold water of the south China Coastal Current (Fig. 3). Such a spread could be caused by the transport of seeds of harmful algal bloom species or by the progression of favorable conditions with the current, or could be due to both

The large-scale transport of red tide species has been recognized as an important mechanism for introducing seed species and spreading harmful algal blcoms of the toxic Alexandrium species along the US
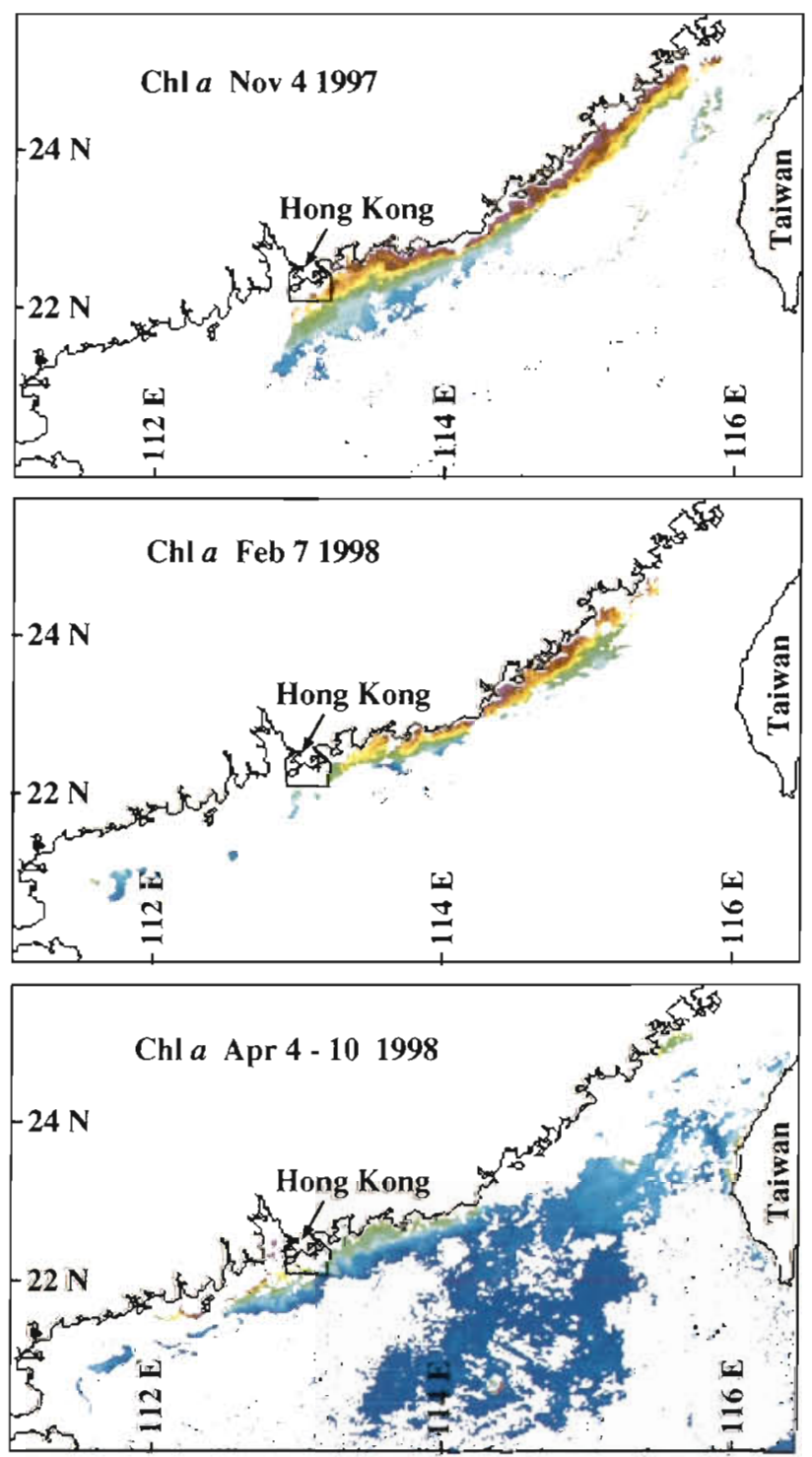

O

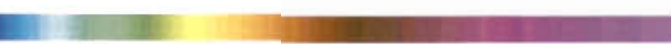

0
4

5 12 
northeast coast (Anderson 1997), brown tide species Aureococcus anophagefferens along the mid-Atlantic coast (Bricelj \& Lonsdale 1997), Gymnodinium breve in the Gulf of Mexico (Tester \& Steidinger 1997), and other toxic species on the US west coast (Horner et al. 1997).

Hong Kong is situated on the south coast of China and opens to the northern South China Sea. The oceanographic conditions of the south China coast and Hong Kong territorial waters are largely influenced by the interaction of 4 water masses in the northern South China Sea: the South China Sea water, the Kuroshio
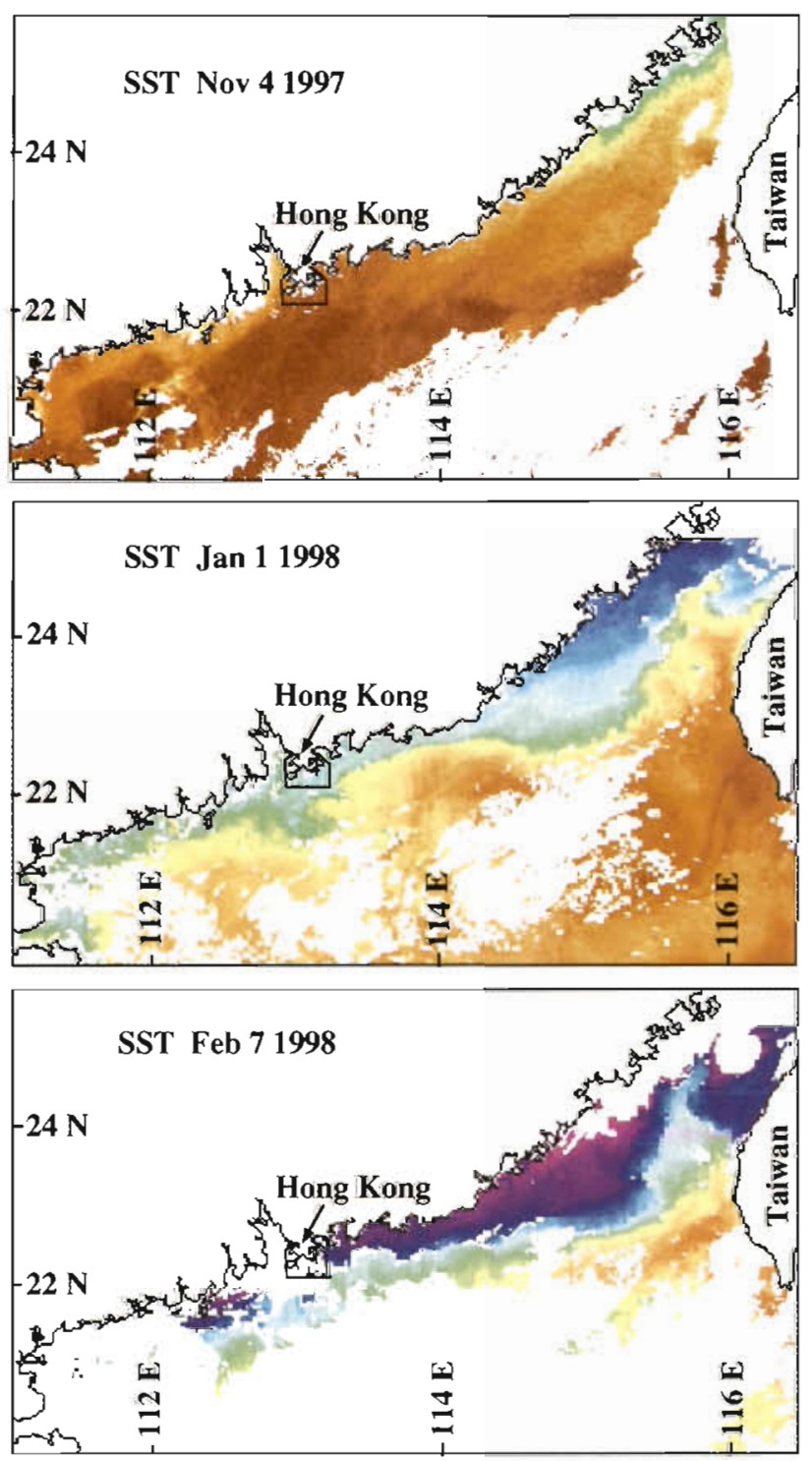

$\begin{array}{llllllllllllllll}14 & 15 & 16 & 17 & 18 & 19 & 20 & 21 & 22 & 23 & 24 & 25 & 26 & 27 & 28 & { }^{\circ} \mathrm{C}\end{array}$

Fig. 3. Satellite images of sea surface (SST) from AVHRR on November 4, 1997, and January 1 and February 7, 1998 current, the China Coastal Current and the Pearl River estuarine plume (Chau \& Abesser 1958, Chau \& Wong 1960, Watts 1971a,b, Morton \& Wu 1975). The influence depends on seasonal monsoons. In winter, when the northeast monsoon prevails, the China Coastal Current flows southwesterly and dominates the inner continental shelf along the south coastal waters of China (Chau \& Wong 1960, Williamson 1970, Watts 1973). This southwesterly movement of the China Coastal Current was clearly indicated by temperature changes from November to February during which cold water of $21^{\circ} \mathrm{C}$ had spread from north of $24.00^{\circ}$ to $22.00^{\circ} \mathrm{N}$ (Fig. 3). Since the China Coastal Current is a seasonal current, then why did large-scale red tides occur during this year? What changed during El Niño in the South China Sea?

Normally, the South China Sea Warm Current runs counter to the China Coastal Current, and moves northeast on the outer continental shelf (beyond a depth of $50 \mathrm{~m}$ ) (SIO 1985, Guang 1994). This current was shown on the weekly composite SSTs (sea surface temperatures) from the satellite AVHRR, which showed a warm tongue pointing towards the north on the western part of the northern South China Sea along Hainan Island (Fig. 4). A warm tongue was evident on the contour lines of temperature of 23,24, and $26^{\circ} \mathrm{C}$ on March 2-8, 9-15, and March 30-April 5, 1997, respectively (Fig. 4). Lying south of the South China Sea Warm Current off Hong Kong, there is a branch of the Kuroshio Current that invades the northern South China Sea from the Pacific Ocean across Lozon Strait (Chau \& Wong 1960, Williamson 1970, Watts 1973, SIO 1985 , $\mathrm{Xu} \& \mathrm{Su}$ 1997). The Kuroshio Current branch in the northern South China Sea may turn southwesterly after it hits the continental shelf (Xu \& Su 1997). A cold tongue in the middle of the South China Sea was evident on the weekly composite SST, as indicated by the contour temperature of salinity of 23,25 and $26^{\circ} \mathrm{C}$ on March 2-8, March 9-15 and March 30-April 5, respectively (Fig. 4). The 3 currents form a sandwich: the south China Coastal Current on the inner continental shelf, the counter South China Sea Warm Current to its south and the Kuroshio Current branch on the continental slope. Because of the interactions of these water masses, coastal waters on the south China coast including Hong Kong are advected and mixed rather rapidly (Watts 1973, Morton \& Wu 1975). This was also indicated by the weekly changes of SST in 1997 (Fig. 4). As a result of fast exchange of the coastal waters with open oceanic waters, in the past Hong Kong has not experienced as many red tides as one would expect during winter and early spring, given that local nutrient input has increased over the years (EPD 1997). However, during El Niño 1997-98, the weekly SST distribution from March to early April in the northern 

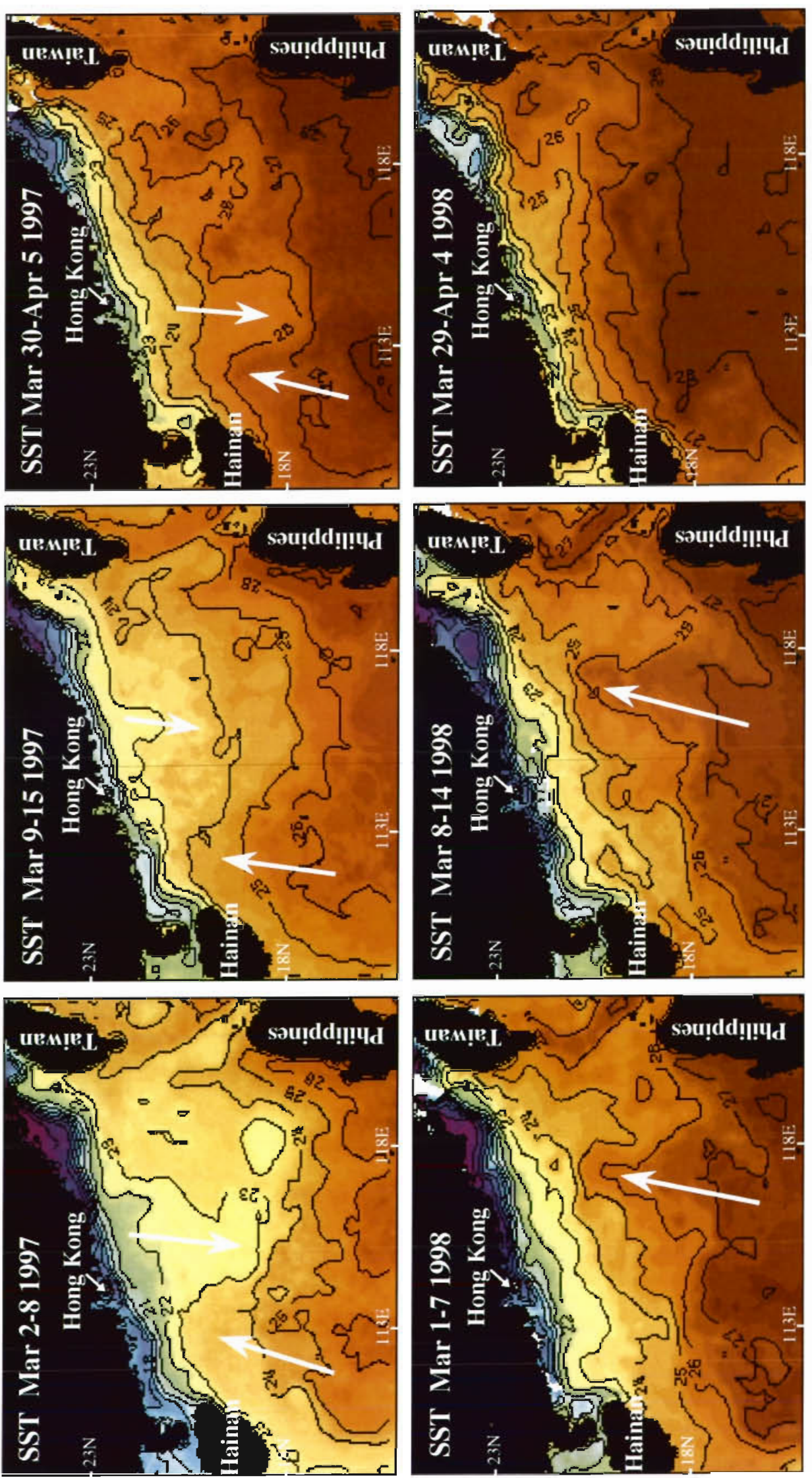
South China Sea changed dramatically (Fig. 4 sompared with SST during the same period of 1997 . First of all, the waters were warmer by at least $1^{\circ} \mathrm{C}$ in 1998 , since contour lines of the same temperature $\left(e .9 .2 .3^{\circ} \mathrm{C}\right.$ ) were further north in 1998 than in 1997 (March 1 10 7 , 1998 vs March 2 to 8, 1997, Fig. 4). Air temperatures in Hong Kong were also higher between October 1997 and May 1998 than the 30 yr average; they were $05^{\circ} \mathrm{C}$ higher in March and $2.5^{\circ} \mathrm{C}$ higher in April (Hong Kong Observatory data). Secondly, the warm tongue on the west side and the cold tongue in the middle, wich were seen in 1997 (Fig. 4), were not evident $x$ disappeared in 1998 (Fig. 4). Instead, the SST mntour tended to form a bell shape or a cross-basin warm tongue pointing to the north in the middle of the north South China Sea in 1998 (Fig. 4). It appears that the South China Sea Warm Current and the invading Kuroshio Current were weakened due to El Ninio and the change suggested that warm waters might. have piled up towards the shore. This similar contrast in the SST distribution was found for the same perion of March to early April between 1983 (El Niño) and 1984 , and 1987 (El Niño) and 1988 (NOAA reynolc:s SST Website data http://www.noaa.gov). Finally, the horizontal gradient of SST along the shore near Hong Kong was larger in 1998 than in 1997, particulary from early to mid-March (Fig. 4), which appeared to be a consequence of a piling up of the warm water against the colder shore waters. The 3 features appecrad to indicate that near-shore waters along the south China coast were more stagnant during March and early April in 1998 than in 1997. In addition, on the south China coast, the northeast monsoon results in mearshore downwelling of the China Coastal Curreblt due to the Coriolis force. However, because of the piling up of oceanic water at the bottom from the South China Sea (bell-shaped SST) due to El Niño, the dourwelled waters might have to move against the oceanic waters underneath and, therefore, could be trapped on the coast. The evidence was found at an environmental monitoring station in eastern and southern open maters of Hong Kong (EPD unpubl. data). At MM14 (F:C. 1), temperature was lower at the surface than at the nearbottom from January to March 1998 (Fig 5). This reversed distribution in temperature also occurrad in January 1997 but disappeared in March. At a death of $26 \mathrm{~m}$, in order to maintain this reversed tempeature distribution between the surface and bottom for a period of almost $2 \mathrm{mo}$, the waters at the surface and bottom had to be supplied continuously. In this case, the surface water was from the south China Coastal Current and the bottom water from the South China SEa. This was supported by the salinity data. Salinity at the nearbottom was 34.4 and 33.3 for January and March 1998, respectively. The former was a characteristic sainity of

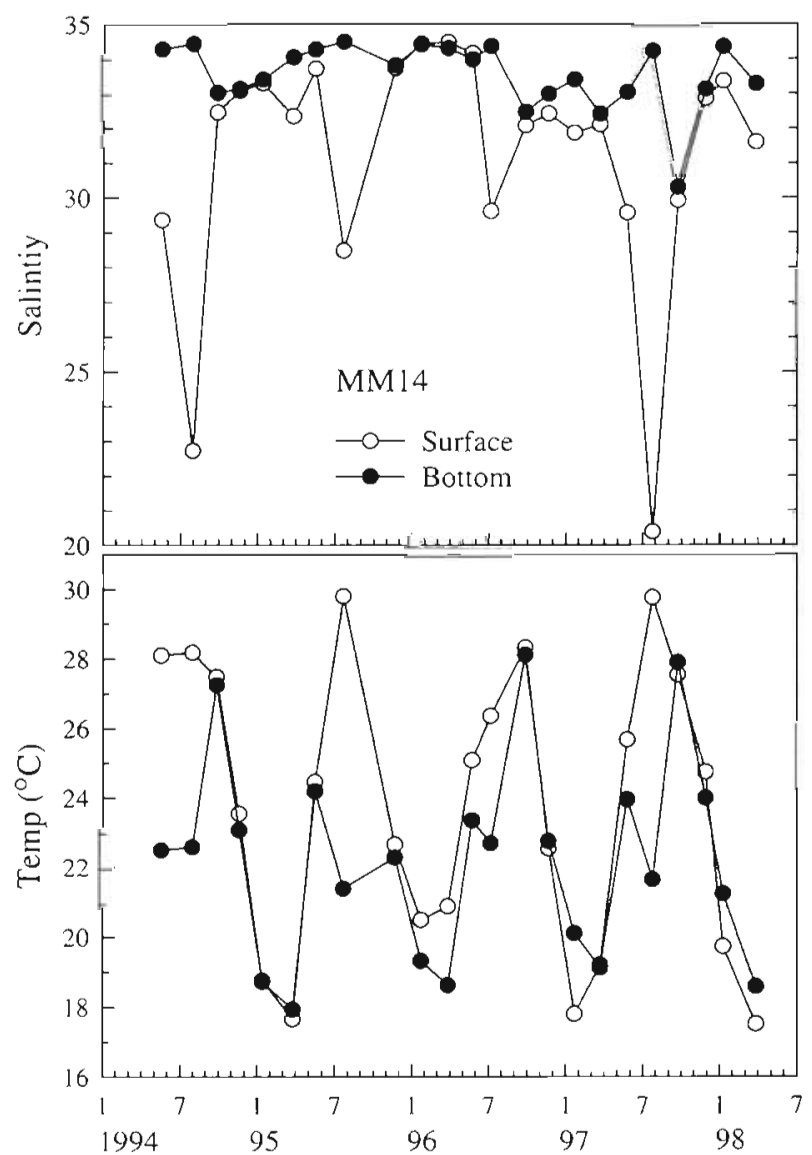

Fig. 5. Time series of salinity and temperature from 1994 to March 1998 at the surface and near-bottom (24 m) in the water column at a marine environmental monitoring station MM14 (Fig. 1). The sampling times for the last 2 data points are January 8 and March 25, 1998. The data were provided by the Hong Kong Environmental Protection Department

the deep shelf water of the South China Sea (Chau \& Wong 1960). These salinities in 1998 were higher by $\sim 1$ than in the same months in 1997 (Fig. 5). This evidence suggested that local waters had been exchanged less during spring 1998 than other years. The downwellingfavorable winds have been reported to be responsible for the trapping of Alexandrium spp. cells in the plume against the shore along the eastern coast of the United States (Anderson 1997). In Hong Kong, primary treated sewage discharges directly to coastal waters and there are many fish farms using trashed fish as well. On average, there are at least 20 occurrences of red tides yearly in Hong Kong territorial waters (EPD 1997). Occurrences of red tides are well correlated with an increase in the population and nutrients (Lam \& Ho 1989). Large amounts of fertilizer are used in China and there are few secondary sewage treatment plants in coastal cities of China. Therefore, nutrient loading must be very high. It is reasonable to believe that local 
nutrient conditions are usually favorable for the formation of harmful algal blooms. When the water column is stable, harmful algal blooms could occur although the exact mechanisms are probably complex.

There have been few studies on the effects of El Niño on physical and biological events in the South China Sea. Our results are the first to reveal the dramatic change in oceanographic conditions in the South China Sea during El Niño and that the series of red tides on a coast-wide scale along the south China coast coincided with this change. The correlation between the occurrence of red tides and El Niño has been implicated for the western Pacific Ocean (Maclean 1989), and other parts of the Pacific Ocean (Erickson \& Nishitani 1985). The brown tide Aureococcus anophagefferencs in 1985 was suggested to be triggered by mesoscale meteorological and/or hydrographic events over a distance of $\sim 500 \mathrm{~km}$ in US mid-Atlantic coastal waters (Cosper et al. 1989, Smayda \& Villareal 1989). Coastal waters in many countries are usually full of sporadic events of harmful algal blooms attributable to eutrophication in normal years. Now, it appears that the effects of long-term accumulation of anthropogenic input of nutrients in coastal waters have reached the point where mesoscale meteorogical and/or hydrographic events, or ocean-wide scale events like ENSO can easily tip off the balance and play an escalating role in altering coastal ecosystems. It is time to take large-scale events into consideration of coastal zone management.

Acknowledgements. We thank Michelle Legault for providing technical assistance in mapping the red tides, Prof. Yuzao Qi for providing the information on red tides occurring in China. Financial support was from 2 grants: the Contract WITI93/94.RC01 and the Pearl River Estuary Pollution Project (PREPP). The PREPP was funded by the Hong Kong Jockey Club. We acknowledge the Agriculture and Fisheries Department and Environmental Protection Department. Hong Kong SAR Government, for providing data on red tides and environmental variables. The facility for the satellite receiving station was funded by the Crouch Foundation, Hong Kong.

\section{LITERATURE CITED}

Anderson DM (1997) Bloom dynamics of toxic Alexandrium species in the Northeastern U.S. Limnol Oceanogr 42 : $1009-1022$

Bricelj VM, Lonsdale DJ (1997) Aureococcus anophagefferens: causes and ecological consequences of brown tides in U.S. mid-Atlantic coastal waters. Limnol Oceanogr 42 1023-1038

Chau YK, Abesser DJ (1958) A preliminary study of the hydrology of Hong Kong territorial waters. Hong Kong Univ Fish J $2: 37-42$

Chau YK, Wong CS (1960) Oceanographic investigations in

Editorial responsibility: Otto Kinne, (Editor),

Oldendorf/Luhe, Germany the northern region of the South China Sea off Hong Kong. Hong Kang Univ Fish J 3:1-25

Cosper EM, Dennison W, Milligan A, Carpenter EJ, Lee C, Holzapfel J, Milanese L (1989) An examination of the environmental factors important to initiating and sustaining 'brown tide' blooms. In: Cosper EM, Bricelj VM, Carpenter EJ (eds) Novel phytoplankton blooms: causes and impacts of recurrent brown tides and other unusual blooms. Springer, New York, p 317-340

EPD (Environmental Protection Department) (1997) Hong Kong Government. Environment Hong Kong 1996. Hong Kong Government Printer

Erickson G, Nishitani L (1985) The possible relationship of El Niño/Southern Oscillation events by records of shellfish toxicity. In: Wooster WS, Fluharty DR (eds) El Niño north: Niño effects in the eastern subarctic Pacific Ocean. Univ Wash Sea Grant Program, University of Washington, Washington, p 283-290

Guang BX (1994) Patterns and structures of the currents in Bohai, Huanghai and East China Seas. In: Zhou D, Liang YB, Zeng CK (eds) Oceanoglogy of China Seas, Vol 1. Kluwer Academic Publ, London, p 17-26

Holden C (1998) Red alert. Science 280:509

Horner RA, Garrison DL, Plumley FG (1997) Harmful algal blooms and red tides on the U.S. west coast. Limnol Oceanogr 42:1076-1088

Kerr RA (1998) Models win big in forecasting in El Niño. Science 280:522-523

Lam CWY, Ho KC (1989) Red tides in Tolo Harbour, Hong Kong. In: Okaichi $T$, Anderson DM, Nemoto $T$ (eds) Red tides: biology, environmental science and toxicology. Elsevier, New York, p 49-52

Maclean JL (1989) Indo-Pacific red tides, 1985-1988. Mar Pollut Bull 20:304

Morton B, Wu SS (1975) The hydrology of the coastal waters of Hong Kong. Environ Res 10:319-347

SIO (The South China Sea Institute of Oceanography) (1985) Chinese Academy of Sciences. Report of multidisciplinary investigation of the South China Sea II. Academic Press, Beijing

Smayda TJ, Villareal TA (1989) The 1985 'brown-tide' and the open phytoplankton niche in Narragansett Bay during summer. In: Cosper EM, Bricelj VM, Carpenter EJ (eds) Novel phytoplankton blooms: causes and impacts of recurrent browr tides and other unusual blooms. Springer, New York, p 159-188

Tester PA, Steidinger KA. (1997) Gymnodimium brevered tide blooms: initiation, transport, and consequences of surface circulation. Limnol Oceanogr 42:1039-1051

Watts JCD (1971a) A general review of the oceanography of the northern sector of the South China Sea. Hong Kong Fish Bull 2:41-50

Watts JCD (1971b) The hydrology of the continental shelf area south of Hong Kong. 1 Oceanographic observation for the year 1969. Hong Kong Fish Bull 2:51-57

Watts JCD (1973) Further observation on the hydrology of the Hong Kong territorial waters. Hong Kong Fish Bull 3:9-35

Williamson GR (1970) The hydrography and weather of the Hong Kong fishing grounds. Hong Kong Fish Bull 1:43-49

Xu JP, Su JL (1997) Hydlrographic analysis on the intrusion of the Kuroshio into the South China Sea. II. Observational results during the cruise from August to September in 1994. Tropic Oceanology 16:1-13

Submitted: January 19, 1999; Accepted: June 2, 1999

Proofs received trom author(s): September 16, 1999 